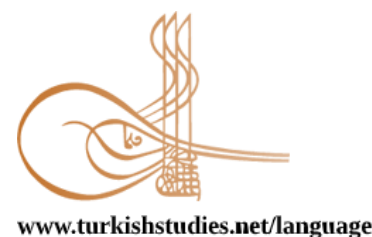

Turkish Studies - Language and Literature

\title{
Hurşit ile Mahmihri Hikâyesinin Arketipik Yapısı Üzerine Bir İnceleme
}

\author{
An Examination On The Archetypa Structure Of Hursit And Mahmihri Folktale
}

\author{
Salih Gülerer*
}

\begin{abstract}
Archetype, which means first example, genuine model, first type; is like the structres that forms cultures. Archetypes creat new notion by gathering and they come to the conscious via myths, dreams and symbols in folktales. According to Jung who is the founder of analytic psychology, humans have the conscious, the personal unconscious and the collective unconscious. In the collective unconscious, there are culturel phenomenons which has brought from their fathers by atavism unwittingly beared by the people, like saga and tale. One of the culturel products which produced by the societies is folktales. It's been transferred by the storyteller minstrel in the chat environment. Even though the stroies which were transferred to the writing look like the individual products, the creator is the society. Story separates from the types likesaga and tale which includes preternaturalnes. The preternaturalnes makes up as the old man archetype in the story. The function of this archetype is limited like; having a baby by giving an apple, providing to be a minstrel and falling love iin the dream and helping hero in the times of trouble. It's splited up in recognition of the topics as love and epic stories. One of the story which treats the love topic is Hursit and Mahmihri. The goal of the work is to determine to archetypes in Hursit and Mahmihri. As the method, "Psychoanalytic Folklore Theory" which is one of the text-based folklore theoy is used. In the story examined, C. Gustav Jung's; old man, anima, individuality, persona, shadow and me archetypes in the personal unconscious and collective unconscious were detected.
\end{abstract}

Structred Abstract: Archetype which means; first example, unique model, first type is like the constituent makes up the cultures. Archetypes emerge the new concepts by gathering and go into the conscience via myths, dreams and symbols in the stories. According to Jung, who is the founder of the analitic psychology, people have conscience, personal unconscious and collective unconscious. One of the cultural productions made by the societies is folktales. In recognition of the subjects, folktales are seperated as love/minstrel and epic stories. Hursit and Mahmihri is a love/minstrel story. The purpose in the work is to determine to the archetypes in the Hursit and Mahmihri story.

The brief review of the story's like that: the sultan has a boy by eating the apple which has been given by the dervish. The young boy, Hursit is wanted to be get married with someone, however he doesn't like anybody. He sees dervishes in his dream. One of the dervishes shows him to the girl who is Hursit going to fall in love with her and recommends him to wait for seven months. When he wakes, both he fell in love with girl and having the power of reading poem, then retrives to the girl.

\footnotetext{
* Dr. Öğr. Üyesi, Uşak Üniversitesi, Eğitim Fakültesi, Türkçe ve Sosyal Bilimler Eğitimi Bölümü Assist. Prof. Dr., Uşak University, Faculty of Education, Department of Turkish and Social Education ORCID 0000-0001-8221-2874

salih.gulerer@usak.edu.tr

Cite as/ Atıf: Gülerer, S. (2020). Hurşit ile Mahmihri hikâyesinin arketipik yapısı üzerine bir inceleme. Turkish Studies - Language, 15(3), 1245-1260. https://dx.doi.org/10.47845/TurkishStudies.44158

Received/Gelis: 11 June/Haziran 2020

Accepted/Kabul: 15 September/Eylül 2020

Copyright $($ INTAC LTD, Turkey
} 
Hursit belongs to the upper class of the society because of his father is the sultan. It's been noticed that when Hursit 16, his parents externalized the imagos from the conscious. To be loved too much by his father, Hursit's femininity and and anima archetype has crystallize. Hursit makes out prominently the "common woman image" by wanting the girl "as beautiful as himself". Even though many woman come to the palace, Hursit can't surpass the common woman image in his unconscious. Anima is his face which is seen by the unconscious. When the personal presure disappears by dreaming, it's been seen that the individualism and collective spirit. The dreams show the a differant situation when the personal fantasies come to light. Conscious personality is a very arbitrary lower part of the collective spirit. Personal is the one that is intrinsic to this person. It's been known situation that conscious and personal spirit ground to hereditary structure and having a connection with the collective spirit. Individualism which Hursit have is going to exhibit a resistance. This resistance makes up with a dreamed dream. It means at the same time getting in touch with the collective unconscious in a spiritual way. Hurist's spirit is not only private and completaly personal, but also collective phenomenon. A seven month pubescence period is condition for Hursit who had a transformation via his dream for to subdue to his own anima and to reach to spiritual maturity. In this period; staying alone, keeping secret and reading poem are the most important steps. With the copetence of reading poem, Hursit's differentation process starts. This process is actually his individualization process.

Captain's darkness of his soul, his shadow, emerges with the guarding task of the city. Captain's powerful feature is to organize and manage the people. Captain's shadow wants to people accept him as "The Great Khan" by stepping forth. By the time, Captain's shadow dominates his ego and takes commend of his conduct. The shadow finds out not only taking the task of the watchman's task, but also wants to take his girl and climb the social ladder.

Hursit has also the masks for handling the situations which he faces through the story and contact with the people. In the first of them, a esquire's daughter had saw him and fell love with him. However Hursit hides his identity in spite of he is the son of the sultan. To build a good relation with the girl he puts forward his "minstrel" identity which is persona archetype. "me" archetype, by organizing the other archetypes and their makin up on the conscious level entegrates the personality. "me"s purpose is make the person's itself real. From the begining of the story, to the end; Hursit is in a struggle for make himself real. Hursit tries for make himself real, and for that he fell in love wtih the effect of the old man in his dream and underwent a transformation from a feminine poem reader to a personality who can make everything for his love. While in the seven month period, that is Hursit's pubescence period, which has been specified by the old man in his dream, cooperate with his own ego and the ego matched to the "me"s calls and enables to Hursit to know himself.

Keywords: personal unconscious, collective unconscious, archetype, Hursit and Mahmihri

Öz: İlk örnek, özgün model, ilk tip gibi anlamlara gelen arketip, kültürleri oluşturan yapı taşları gibidir. Arketipler bir araya gelerek yeni kavramlar oluşturur ve bilince mitler, rüyalar, hikâyelerdeki semboller yoluyla gelirler. Analitik psikolojinin kurucusu olan Jung'a göre insanlarda bilinç, bireysel bilinçdışı ve kolektif bilinçdışı mevcuttur. Kolektif bilinçdışında İnsanların soyaçekim yoluyla atalarından getirdiği ve farkında olmadan taşıya geldiği destan, masal gibi kültürel olgular da bulunmaktadır. Toplumların ürettiği kültürel ürünlerden biri de halk hikâyeleridir. Sohbet ortamlarında hikâyeci âşık denilen anlatıcılar tarafindan aktarılmıştır. Zamanla yazıya geçirilmiş hikâyeler bireysel ürünler gibi görünseler de yaratıcısı aslında halktır. Hikâye gerçekçiliğe olan eğilimiyle destan, masal gibi içerisinde olağanüstülüğü çokça barındıran türlerden ayrılmaktadır. Bu anlamda hikâyedeki olağanüstülük ihtiyar adam arketipi olarak ortaya çıkar. Bu arketipin işlevi; elma vererek çocuk sahibi olmak ve kahramanın rüyasında âşık olmasını ve âşıklık kazanmasını sağlama; zor durumlarda kahramana yardım etmek gibi sınırlı sayıdadır. Konuları bakımından aşk ve kahramanlık hikâyeleri olarak ikiye ayrılır. Aşk konusunu işleyenlerden biri de Hurşit ile Mahmihri hikâyesidir. Çalışmada amaç, Hurşit ile Mahmihri hikâyesinde yer alan arketiplerin çıkarılmasıdır. Yöntem olarak metin merkezli halkbilim kuramlarından "Psikoanalitik Halkbilim Kuramı" kullanılmıştır. İncelenen hikâyede C. Gustav Jung'un bireysel bilinçdışı ve kolektif bilinçdışında yer alan ihtiyar adam, anima, bireysellik, persona, gölge ve ben arketipleri olduğu tespit edilmiştir.

Anahtar Kelimeler: bireysel bilinçdışı, kolektif bilinçdışı, arketip, Hurşit ile Mahmihri 


\section{Giriş}

Destan, masal, efsane, hikâye gibi halk edebiyatı türlerini kendi çalışma alanının malzemesi olarak kullanan psikolojinin yanı sıra halkbilimde de psikolojik bir yönteme de ihtiyaç duyulmuştur. $\mathrm{Bu}$ yöntem de metin merkezli halkbilim kuramlarından biri olan "Psikoanalitik Halkbilim Kuramı"dır. Bu kuram W. Wundt, Sigmund Freud ve C. Gustav Jung'un adı etrafinda oluşmuş ve gelişmiştir. Edebiyatla psikoloji arasında yoğun bir ilişki söz konusudur. Örneğin, Türk halk hikâyelerinde geçen rüya ve rüyayla bağlantılı birçok unsurun incelenmesinde psikolojiye de ihtiyaç duyulmaktadır. W. Wund'un Okulu halkbilim ürünlerinin kaynağını düş, imge ve hülya gibi psikolojik oluşumlarla ele almaktadır (Çobanoğlu, 2005: 152). S. Freud, Rüyaların Yorumu adlı iki ciltlik eserinde rüyaları yorumlamayı mümkün olan bir teknik bulunduğunu ve bunun uygulanmas1 durumunda her rüyanın, bir anlamı olan ve uyanık yaşamın ruhsal etkinliklerinde belirlenebilecek bir noktaya bağlanabilen bir ruhsal yapı olarak belirdiğinin kanıtlarını ortaya koyacağını iddia etmektedir (Freud, 2000: 55). Freud'un rüya yorumlaması, bireyin bastırılmış kişisel geçmişiyle ve çocukluk arzularyyla sınırlıdır. Bu yöntemde halkbilim ürünlerini psikolojide simgeleme yoluyla kullanan C. Gustav Jung, rüya konusuna yeni bir yorum getirerek, "Freud'un rüyanın aslında bir arzu giderme olduğu görüşüne karşı olarak ben, rüyayı bilinçdışının fiili durumunun sembolik bir formda kendini resmetmesi olarak görüyorum. Bizim formülümüz basitçe rüyanın bilinçdışı bir içeriğin sembolik temsili olduğunu söylüyor.” demektedir (Jung, 2017: 63) C. G. Jung'a göre "Rüyaların bastırılmış arzuların hayalen giderilmeleri olduğu düşüncesi güncelliğini yitirmiştir. Rüya kaçınılmaz gerçekler, felsefi açıklamalar, yanılsamalar, fanteziler, anılar, planlar, beklentiler, mantıksız deneyimler, hatta telepatik görüler ve daha neler içerebilir. Rüya tam olarak bilinçdışının yansımasıdır" (Jung, 2017: 112).

Analitik psikolojinin kurucusu olan Carl Gustav Jung (1875-1961) İsviçrelidir. Çalışmaları sadece psikoterapi bilim dalını değil psikoloji, teoloji, etnografı, edebiyat ve güzel sanatları da etkilemiş̧tir. Jung'un psikolojide ortaya koyduğu arketip, kolektif bilinçdışı, persona, anima ve animus gibi kavramlar yaygın kabul görüştür. C. G. Jung'un ileri sürüp açıkladığı kavramları halk hikâyelerini göz önünde bulundurarak yorumlayabiliriz. Buna göre, arketipler bilincin ortaya çıkmasından önce var olan kavrayış biçimleridir ve sezginin doğuştan gelme koşullarıdır. İçüdülerin kendine özgü belirli bir hayat sürmeye zorlamaları gibi arketipler de sezgi ve kavrayışı insana özgü biçimlere zorlarlar.

Kahramanın "ayrılma-aşama-dönme" şeklindeki döngüsü "aşama arketipi"dir. Așama arketipi, halk hikâyesinde kahramanın/kahramanların "uyuma-rüya görme aşaması-dönüşüm içinde uyanma" şeklindeki arketiptir. Bu anlamda halk hikâyelerinde geçen Hızır (yaşlı bilge adam, pir, ihtiyar adam, kırklardan biri) arketipi de öne çıkmaktadır. İhtiyar adam (Hızır) hikâyenin kahramanına/kahramanlarına bir şey (bade, dolu, aşk şerbeti, aşk şarabı, aşk şurubu, aşk dolusu, gönül şarabı vs) içirerek uykusunda dönüşüm geçirmesini sağlamış olur. Bu dönüşümün, aşk hikâyelerinde görülen rüyada iki türlü olduğu görülmektedir. Bunlardan birincisi kahramanın rüyasında bir kızın/erkeğin ya bizzat kendisini ya da resmini görmesi ile başlayan karşı cinse âşı olma dönüşümüdür. Kahraman bu tip uykudan uyandığında âş̧k olmanın (aşka düşme, aşk hastalığ 1 , kara sevda vs) etkilerini uyku uyuyamama, diğer insanlarla konuşamama (içine kapanma), yemek yiyememe (ya da yememe) bazen de saz çalıp deyiş söyleyerek derdini dile getirme olarak gösterir. Aynı dönüşüm bazı hikâyelerde hikâyenin kadın kahramanı için de geçerlidir. Ancak erkek kahramanda görülen aşk hastalığı belirtileri kadın kahramanlar için bahsedilmemektedir. İkinci dönüşüm ise eski hayatında saz çalıp deyiş söylemeyi bilmeyen ya da âşıkların yanında çırak olarak verilen ancak bir türlü doğru dürüst çalıp söylemesini beceremeyen genellikle erkek bazen de kadın kahramanın âşıklık yetisine ulaşmasıdır.

Eskiden beri insanların "küçük" ve "büyük" rüyaları birbirinden ayırdığı görülmektedir. Buna göre "küçük" sayılan rüyalar, öznel ve kişisel alanda günlük olaylarla sınırlıdır. Asıl olan "büyük" ya da "önemli" rüyalardır ve insanlığın zihin tarihinde de karşılaştı̆̆ımız sembolik 
imgeleri içerirler. Bunların bireysel vaka malzemelerinde ve evrensel olarak sık sık görülmeleri, insan psişesinin eşsiz ve kısmen kişisel olduğunu, geri kalanının ise ortak ve nesnel olduğunu kanitlamaktadır. O halde bir yandan kişisel, bir yandan da daha derinde yer alan ortak bilinçdışından bahsedilmektedir (Jung, 2017:93). Bütün insanlarda ortak olarak bulunan bu bilinçdışı, kalıtım yoluyla ile soydan gelen ve bütün geçmişi içeren izlenimlerdir. Ortak bilinçdışı kişisel bilinçdışının daha da derinde olan yönüdür. Daha önce de ifade ettiğimiz gibi kalıtımsal bir nitelik taşır ve bireye atalarından aktarılırlar. İnsanlığın geçmişini içeren halk ürünlerinin temeli ortak bilinçdışının içeriğini oluşturan arketiplerdir.

Jung (2016) bireyselleşme için "insanın kendi olması" ya da "kendini gerçekleştirme" tanımını kullanmaktadır. Bireysellik kişinin kendi olması demektir. Ona göre belli bireyselleşme belli bireysel özellikleri oluşturan psikolojik gelişme anlamına gelebilir; yani kişinin gerçekte olduğu ve benzeri olmayan bir varlık olma vetiresidir (Jung, 2016: 197-198). İnsan beyninin zihinsel işlevi, bireysel olduğu kadar aynı zamanda kolektif ve evrenseldir. Farklı insan gruplarının bilinçdışı süreçlerinin benzerlik sergilemesi kadim mitos ve motifleri arasındaki sıra dişı ama doğruluğu kanıtlanmış mütekabiliyetler göstermesini açılamaktadır. Mitolojik ve dini motiflerin rüyada ortaya çıkması kollektif bilinçdışının varlığına işaret eder (Jung, 2016: 170-183). "Büyük", "önemli" rüyalar kahramanın doğası gereği pek çok mitolojik motifi ortaya çıkar. Kahramanın gördügü "rüya" ve "Hizır/ihtiyar adam" kolektif bir imgedir. Bu tip imgelerin zuhuruyla birlikte kahramanın gördüğü rüyasındaki aşk dolusu, sevgilinin kendisi ya da resmiyle ilk defa karşılaşma, âşıklık yetisi kazanma sıradan bir rüyada kesinlikle rastlanamayacak şeylerdir. Halk hikâyelerinde kahramanların gördüğü rüyaların aşağı yukarı her hikâyede birbirine benzer bir şekilde görülmesi kollektif bilinçdışının bir göstergesidir.

Jung (2016) kolektif ruhun genellikle büyük 1stıraplar pahasına şekillenen alt kesitine "persona" adını vermiştir. Bu terim oyuncuların taktığı ve oynadıkları rolü gösteren maske anlamına gelmektedir. Persona bireyselmiş gibi görünse de aslında kolektif ruhun bir maskesidir. Bireyselliğe öykünen kişinin kendisi ve ortak ruhun konuştuğu bir rol oynayan bu durumun bireysel olduğuna inandıran bir maskedir. Bu maskeyi çıkardığımızda bunun kolektif ruhun maskesi olduğunu görürüz. Persona, kişinin çevresine nasıl görünmesi hususunda toplumla olan uzlaşmasıdır (Jung, 2016: 180-181).

Jung, her insanın içinde ikinci bir kişilik olduğunu söyler. İçimizdeki bu gizli kişiliğe yani karanlık tarafa "gölge/karanlık arketipi" adı verilmiştir. Bu arketip sadece bir insanın içinde değil topluluğa da (dini gruplar, partiler vs) sahip olabilir. Gölgenin üzerine ne derece baskı uygulanırsa o ölçüde tehlike arz eder. Jung'a göre iki tip gölge vardır. İlk olarak kişisel gölge; kişisel olarak ferdin korku, endişe, bencillik ve hayal kırıklıklarını gösterir. İkincisi toplumsal gölge acımasızlık, vahşilik, soykırım gibi yansımaları olur. Her insanın içinde gölgesi mevcuttur. Gölge, insan ruhunun kötü yanını temsil eder. Eğer kişi bu yönünü gizleyip susturmaya çalışırsa bu kişiyi hasta edebilir. İnsanın bilinçdışında karanlık ve kötülük buharlaşı uçmamıştır enerji kaybından dolayı bilinçdışına doğru saklanmış ve bilinçte işler yolunda olduğu sürece ortaya çıkmayacaktır (Jung, 2011: 145).

Konuyla ilgili makalesinde İbrahim Gürses (2007) C.G. Jung'un çalışmaları hakkında bilgi vererek özellikle kolektif bilinçdışı kavramı ve arketipleri, "Simurg" adlı tasavvufi bir öykü üzerinden incelemiştir. Okan Alay (2012) Bir masal ve Gündeşoğlu adlı bir halk hikâyesini arketipsel tahlilini ele almıştır. Makale J. Campbell'in Türkçeye "Kahramanın Sonsuz Yolculuğu" adıyla çevrilmiş eserindeki yolu esas almıştır. Uğur Ava'nın "Türk Halk Hikâyelerinde Arketipsel Sembolizm" adlı yayınlanmamış yüksek lisans tezinden hareketle yazılan makale, Yılmaz Irmak ve Uğur Ava (2017) Âşık Garip Hikayesini Joseph Campell'in adı geçen eserinde ele aldığı yolla "ayrılık-erginleşme-dönüş" aşamaları içerisinde persona, gölge, anima-animus, ve yüce birey arketipleri bağlamında incelemişlerdir.. 
Hurşit ile Mahmihri Hikâyesi, anlatı yapısında bulundurduğu birçok sembol ve arketipler yönüyle psikanalitik çözümlenmesi yapılabilecek bir eserdir. Hikâye diğer birçok halk hikâyelerinde olduğu gibi bir ihtiyar adamın verdiği elmalar sayesinde dünyaya gelen kahraman, bir padişahın oğludur. Rüya görerek dönüşüm geçirmiş ve âşık olduğu kıza kavuşmak için yaşadığı serüveni ele alan konusuyla bir aşk hikâyesidir. Hurşit ile Mahmihri Hikâyesi adıyla Kültür bakanlığı tarafindan basılan Saim Sakaoğlu ve Ali Duymaz'ın araştırma kitabında o tarihe kadar hikâye üzerine yapılmış çalışmaları, hikâyenin varyantları bunların yapı bakımından karşılaştırılması ile sonuçta metinlerine yer verilmiştir. Bu makalede Fevzi Gürgen tarafından sözlü gelenekteki anlatı örnek alınarak yazılan ve Sağlam Yayınevi tarafından 1973 yılında basılan hikâye kitabı esas alınmıştır. Hurşit ile Mahmihri hikâyesinin epizotları çıkarılmış ve bu epizotlarından uygun olanlarının devamında psikanaliz çözümlemesi içinde bireysel ve kolektif ruhun yansımaları olan ihtiyar adam, anima, persona, gölge/karanlık, ben arketiplerinin tespiti yapılmıştır.

\section{Hurşit ile Mahmihri Hikâyesinin Epizot Yapısı ve Epizotlara Bağlı Arketipler}

\section{Kahramanların Doğumu:}

Hikâyenin erkek kahramanı Hurşit'in doğduğu yer "Genç Karabağ" adını taşıyan ülke olarak geçmektedir. Burası büyük olasılıkla Azerbaycan Karabağ bölgesinin yakınlarındaki Gence (Gäncä) şehri olmalıdır. Hikâyenin kadın kahramanı Mahmihri ise İçmaan adlı bir şehirde doğmuştur (Gürgen, 1973: 4-7).

Hikâyenin erkek kahramanı Hurşit'in doğumu olağanüstüdür. Genç Karabağ ülkesinin padişahı Tekin'in bir kızı olmasına rağmen yerine geçecek erkek çocuğu olmamaktadır. Yaşı da ilerlemiş padişah oğlu olmamasından kaynaklanan sıkıntısını kendisine ait bir bahçede vakit geçirerek unutmak ister. Bu amaçla saraydan epey uzak bahçeye gittiğinde aksakallı bir ihtiyarla karşılaşır. Padişah hakkındaki her şey kendisine malum olan aksakallı ihtiyar padişahla arasında geçen diyalogda herhangi bir yere girmesi için kimsenin iznine ve kilide ihtiyacı olmadığını ve padişahın bir oğlana sahip olması için Tanrı'ya dua için geldiğini söyler. Bunun üzerine padişah ihtiyarı memnunlukla karşılar. Aksakallı ihtiyarın duasından sonra gaipten biri sarı diğeri kırmızı iki elma meydana gelir. İhtiyar, elmalardan birini padişahın diğerini de hanım sultanın yemesi halinde bir oğlan çocuklarının olacağını söyler. Padişah, aksakallı ihtiyara iltifat edip sarayda ağırlamak ister ancak ihtiyar birden gözden kaybolur. Padişah ihtiyarın öğütlediği gibi kendi ve karısı elmaları yerler. Bunun sonucunda hanım sultan gebe kalır. Vakti dolunca bir oğlan doğurur. Adını "Hurşit" koyarlar. Hikâyenin kadın kahramanının doğumunda herhangi bir olağanüstülük yoktur. İçmaan şehrinde bir bezirgânın yedi oğlu ve çok güzel bir kızı vardır. Kızın adı "Mahmihri"dir (Gürgen, 1973: 3-7).

\section{1. İhtiyar Adam Arketipi}

Arketip, ilk örnek, as1l numune, özgül model gibi anlamlara gelmektedir. İnsanlar geçmişten günümüze karşılaştıkları benzer kişi ve olayları bu süreçte belli davranış kalıpları içine yerleştirmiş ve bu yapıyı edebi ürünlerin içinde de muhafaza etmiştir. Bu anlamda ilk tip ve kalıp şeklindeki yapılar kültürün yapı taşlarını oluşturmaktadır denilebilir (Jung, 2011: 5). Bir yerlerde "göksel bir yerde", "ruh" ile ilgili tüm fenomenlerin öncesinde ve üstünde bir "ihtiyar adam" imgesi bulunmaktadır. İhtiyar adam arketipinin Türk kültüründeki karşılığı Hızır'dır. Bu hikâyedeki gibi Hızır çoğunlukla nur yüzlü, ak saçlı veya aksakallı ihtiyar bir kişi olarak görünür. Hangi durumda ve ne şekilde Hızır'la karşılaşılacağı bilinmez bu yüzden kişinin başından olay geçtikten sonra kendisine yardımcı olan kişinin Hızır olduğuna kanaat getirilir. Halk arasında Hızır kimliğine atfedilen olağanüstü özelliklerden dolayı aksakallı ihtiyara padişahın kim olduğunu ve derdinin ne olduğu malum olmuştur. Halk arasında darda/zorda kalanlara yardımcı olan kimliğiyle padişaha ondan yerine veliaht olarak geçecek bir oğlan çocuğu sahibi olması için Tanrı'ya dua etmesi isteğini yerine getirerek Tanrı'ya dua eder (Gülerer, 171). 
Âdem ile Havva'nın cennetten kovulma kıssasında hem Tevrat hem Kur'an'da "yasak ağaç" olarak geçmesine rağmen halk arasında bu ağacın elma ağacı meyvenin de elma olduğu yönünde yaygın bir inanç vardır (Kitabı Mukaddes, Tevrat, Tekvin, Bap 2, 9-15, s.2-3; Kur'an-1 Kerim, Araf Suresi, ayet 19-24). Yasak ağacın meyvesini yemek cinsel birleşmeyi sembolize etmektedir. Bu durumda kadının verimliliğini temsil eden simge ise "elma"dır (Abraham, 2017: 30). Padişah ve karısı, çocuk sahibi olabilmek için elma yeme ve normal bir şekilde çocuk sahibi olamamanın getirdiği üstü kapalı bir suçluluk duygususuyla doğacak çocuğu şımartacaklardır (Jung, 2017: 45). İhtiyar adamın duası üzerine biri sarı biri kırmızı iki elma gaipten peyda olur. Kültürümüzde sarı renk ayrılığı, kırmızı ise şiddetli aşkı simgelemektedir. İhtiyar adamdan elmayı alan padişah onun tembihlerine uyarak çocuk sahibi olur. Hikâyelerdeki babanın erkek çocuk sahibi olamamasının çözümü, Hızır'ın iki farklı renkte elma vererek dolaylı yoldan babanın rolünü üstlenmesidir diyebiliriz. Hızır, bu rolü hikâyede hem erkek hem kadın kahramanının rüyasına girip birbirlerine âşık olmalarını sağlayarak da yerine getirmeye devam eder.

\section{Kahramanlarm Ailesi:}

Hikâye kahramanlarından Hurşit'in ailesi Genç Karabağ'ın padişahı, annesi de hanım sultandır. Bunun yansıması olarak çocuk büyüyüp okuma çağına gelince zamanın en değerli öğretmenlerinden ders alarak hem eğitimi hem terbiyesi yönünden olumlu bir süreçten geçer. Hikâyenin diğer kahramanı Mahmihri'nin babası bezirgândır. Annesi hakkında herhangi bir bilgi verilmemiştir. Baba İçmaan şehrinin kolcusu aynı zamanda çok zengindir. Mahminri’nin eğitimi hakkında herhangi bir bilgi verilmemiştir. Dolayısıyla kızın ailesi de toplumun üst gelir seviyesindendir. Yedi erkek kardeşi vardır. Babaları ölünce ailenin geleceği hakkında kardeşler karar verirler.

Hikâye kahramanlarından Hurşit 16 yaşına geldiğinde babası onu evlendirmek ister ve bu amaçla saraya memleketin güzel kızları çağrılmaya başlanır. Bu uygulama bir süre devam etmesine rağmen Hurşit bu süreçte hiçbir kızı istemez. (Gürgen, 1973: 5-7-12).

\subsection{Anima Arketipi}

Hikâyenin erkek kahramanı Hurşit'in babasının padişah annesinin de padişah hanımı olması sebebiyle toplumun üst tabakasına dâhildir. Genç Karabağ'ın padişahı denmekle birlikte buranın yerel en üst düzeyde yöneticisi bey ya da han olmalıdır. Hurşit'in doğum aşamasından sonra anne bir köşeye atılmış gibidir. Aynı şekilde kız kardeşinden de hiç bahsedilmez. Sanki anne ve kız kardeşiyle hiçbir akrabalık bağı kalmamış gibidir. Baba ise oğluna büyük bir özveriyle bağlıdır. Oğlunun bütün naz ve kaprislerine hep olumlu bir yaklaşım sergiler. Hikâyede aileyi oluşturan kişiler üç kişiye indirilmiştir. Babanın rolünü üstüne alan ihtiyar adam, baba ve oğlu şeklindedir (Rank, 2016: 101). Hurşit'in babası tarafından aşırı sevilmesi, okşanması ve nazlı bir şekilde büyütülmesinin etkisiyle içindeki kadınsı yönüyle anima arketipinin yansımasının belirginleştiği görülür. Hurşit, evleneceği kızın en az "Kendisi kadar güzel!" olmasını istemekle ve devamında da "Böyle bir kız bulmak mümkün müdür?" diye sormakla içindeki "ortak kadın imgesini" belirgin olarak ortaya çıkarmaktadır. Babası bu durumun farkında olmakla birlikte memleketinde güzel bir kız bulacağını ve Hurşit'in bu tavırlardan kurtulacağını ummaktadır. Her gün yüzlerce kız saraya geldiği halde Hurşit bilinçdışındaki ortak kadın imgesini bir türlü aşamaz. Anima, onun bilinçdışı tarafından görünen yüzüdür.

\section{3. Âşık Olma:}

Saraya gelen hiçbir kızı beğenmeyen Hurşit karmaşık duygular içinde geceleyin farklı bir rüya görür. Rüyasında Karabağ ülkesinin Murattepe adlı mevkide kırk derviş vardır. $\mathrm{Bu}$ dervişlerden biri Hurşit'e "Sana layık olan kız seni bekleyip durur. Adı Mahmihri'dir." dedikten sonra kızın yerini tarif eder. Bu tarif üzerine o yere giden Hurşit orada işaret edilen kızı görerek âşık olur. Dervişler yedi ay sonra kızın ona geleceğini ve bu durumu kimseye söylememesi gerektiğini tembih ederler. Sonrasında Hurşit rüyasından uyanır (s. 6). Hikâyenin kadın kahramanı 
Mahmihri'nin âşı olması da rüya yoluyla olur. Hurşit'in rüyasına giren dervişler aynı gece kızın da rüyasına girerek Hurşit'i Mahmihri'ye gösterirler. Böylelikle hikâye kahramanları birbirlerini gerçekte görmeden rüya yolu ile âşık olmuş olurlar. Bu aşkın tezahürü Hurşit'te çok daha belirgin ve yıkıcı olmuştur. Günden güne düzeni bozulup sararıp solar. Yüzü gülmez yemez içmez olmuştur. Babası oğlunun bu haline üzülür ve memleketin ünlü hekimlerini çağırtır. Ancak onlar hastalığın hekimlik olmadığını Hurşit'in "kara sevda"ya tutulduğunu ifade ederler (Gürgen, 1973: 5-7). Hurşit, dervişlerin öğ̈dünü tuttuğundan derdini kimseye açamamanın sıkıntısını yaşamaktadır. $\mathrm{Bu}$ haleti ruhuye ile kırlarda bayırlarda dolaşıp derdini kuşlara çiçeklere şiir okuyarak ifadeye başlar:

Garip bülbül, sana bir minnetim var,

Aklımı götürdü gözü mestâne

Söylerim sırrımı, veresin haber,

Âşık olup düştüm dile destâna

Bîçâre Hurşit'in hasretin çeker;

Ayrılık ateşi sinemde tüter;

Bahar günlerinde seyrana çıar

Aklımı Kaçırdım oldum divâne (Gürgen, 1973: 8)

Hurşit beyitleri okudukça kanlı yaşlar dökerek ağlamaya ve aşk ateşi içini daha da çok yakmaya başladı. Artık güzel şiir söyleyebiliyor dağa, taşa, kuşa her şeye hayal ettiği sözleri beyit haline getirmekte ustalaşır:

Bir sevdaya düştüm ben yeni baştan,

Gözlerim görünmez kan ile yaştan.

Hak saklasın sizi yırtıcı kuştan,

Yüz tutup da hakka giden turnalar (Gürgen, 1973: 9)

Hurşit gördüğü rüyanın akabinde artık şairlik yetisini kazanmış olur.

\subsection{Kolektif Ruh}

Rüya görmeyle birlikte kişisel bastırmalar kalkar kalkmaz bireysellik ve kolektif ruh bir arada ortaya çıkmaya başlar. Kişisel fantezilerin kendini açığa çıkarmasında rüyalar farklı bir durumu gösterir. Bilinçli kişilik kolektif ruhun çok keyfi bir alt kesitidir. Kişisel, sadece bu kişiye özgü olandır. Bilinçli ve kişisel ruhun kalıtsal bir yapıya dayandığı ve kolektif ruhla bağlantısı ortaya çıtığ 1 bilinen bir durumdur (Jung,1917: 180-183). Hurşit’te var olan bireysellik bir direniş sergileyecektir. Bu direniş görülen rüya ile ortaya çıkar. Bu aynı zamanda kolektif bilinçdışıyla ruhsal bir ilişki kurmasıdır. Hurşit'in ruhu müstakil ve tamamen bireysel olmayıp aynı zamanda kolektif bir olgudur. Hikâyedeki "rüya" sadece Hurşit'e özgü bir durum değildir. İnsan beyninin her yerde benzer olması, tek tip zihinsel işlevin geçerli olmasına yol açmaktadır (Jung, 2017: 170). Halk hikâyelerinde örneğin, Kerem ile Aslı, Derdiyok ile Zülfi Siyâh, Asuman ile Zeycan vs gibi rüyada âşı olma motifi ortaktır. Bu Türk toplumunun kolektif bilinçdışının bir tezahüründen başka bir şey değildir.

\section{2. İhtiyar Adam Arketipi}

Rüyada yaşanan serüvene çağrı, kahramanlara rüyada gösterilen kadın/erkek figürü Hurşit ile Mahmihri Hikâyesinde, Hurşit'in rüyasına kırk derviş girer. Dervişlerden biri âşık olacağı kızın 
ona geleceği haberini verir. Türk halk hikâyelerinin önemli bir kısmında ihtiyar adam, pir, derviş, kırklardan biri şeklinde aslında Hızır görülmektedir. Bu hikâyede de Hızır diye belirtilmese de kırk dervişten biri diye bahsedilen Hızır'dır. Hikâyelerdeki Hızır, yazgıya yön verme gücüne de sahiptir. Sadece erkek kahramanın değil kadın kahramanı Mahmihri'nin de rüyasına girerek onları birbirine âşık eder. (Gülerer, 2019: 183).

Emosyon adı verilen bir takım ruhsal durumların vücudun ruhsal etkinliklerine katılımı çok belirgin ve kapsamlıdır. Emosyon hem bedensel hem ruhsal olarak insanda büyük değişimlere yol açar (Freud, 2000: 37). Hurşit'in gördüğü rüyadan sonra uyku uyuyamama, yemek yiyip içememe içine kapanmayla ortaya çıan üzüntü, tasa gibi depresif karakterdeki emosyonlar çevresinin hemen dikkatini çeker. Hurşit'i bu durumdan kurtarmak için çaba sarf ederler.

\section{Sevgiliyi Arama ve Engeller:}

Hurşit üzgün ve ümitsiz kırda bayırda dolaşırken rastladığı kişilerden aşkını sorar. Örneğin Bezirgân, Hurşit karşılaşması:

Aldı Hurşit:

Belirsiz bir yerdir benim sorduğum

Mahmihri’dir benim güzel sevdiğim

Etlerim eridi, kaldı kemiğim,

Yârimden bir haber var mı bezirgân?

Ald1 Bezirgân:

Yeryüzünü karış karış bilirim,

Ben senin yoluna kurban olurum,

Her kimi sorarsan haber veririm,

Söyle beyim haber var mı yârinden (Gürgen, 1973: 11)

İçmaan şehrinin kolcusu olan Mahmihri'nin babası ölünce memleketi koruma işini ölen kolcunun adamlarından Kara Yüzbaşı adında kötü kalpli birine verirler. Kara Yüzbaşı yönetimi ele alınca ilk olarak kendisini "Büyük Han" ilan eder. Yönetimini pekiştirmek için kuvvetli bir ordu kurma çabaları içine girer. Kendini yeterince güçlü hissettiğinde ölen kolcunun yedi oğlunu huzuruna çağırarak Mahmihri'yi kendisine ister. Kardeşler kendilerine yapılan bu davranışı ve yapılan teklifi yakışıksız bulup cevap vermeden huzuru terk ederler. Zorba yönetici arkalarından haber yollayarak eğer razı olmazlarsa kız kardeşlerini zorla alacağını bildirmesi hikâyedeki en önemli engeli teşkil eder (Gürgen, 1973: 13).

Diğer bir engel ise Hurşit'in âş̧ı olduğu kızın kim olduğunu söylememesidir. Genç Karabağ'daki üç kafadar arkadaş Padişah'ın huzuruna çıkarak Hurşit'e içki içirip derdinin ne olduğunu öğrenebileceklerini söylerler. Çaresiz olan padişah istemeye istemeye razı olur. Üç kafadar planlarını yürürlüğe koyarak içki meclisinde aşktan, sevdadan ve sevgiliden söz açıp Hurşit'e şiirler okuturlar:

Hurşit'im görmüşüm Mahı

Çıkmaz yüreğimden ahı,

Dört kitabın kıblegâhı

Belki yâr gelir yâr gelir (Gürgen, 1973:15) 
Hurşit'i içirip sarhoş eden kafadarlar onun şiirlerinden hareketle padişaha oğlunun "Mahmihri" adında bir kıza âşık olduğunu bildirirler. Bu durum üzerine padişah oğluna çağırarak durumu sorunca Hurşit ona da beyitle cevap verir:

Kırklar içirdiler abı hayatı

Yedirdiler bana bir aşk nebatı;

Bir yol daha görsem o mah sıfat1;

Kâmil olan gelsin benim yanıma (Gürgen, 1973:17)

\subsection{Bireyselleşme Arketipi}

Gördüğü rüya ile bir dönüşüm geçiren Hurşit'in animasını bastırabilmesi ve ruhsal olgunluğa erişebilmesi için rüyasında dervişler tarafindan konulan yedi aylık bir erginleşme süresinin geçmesi gerekmektedir. Bu süreçte yalnız kalma, sır saklama ve şiir söylemeye başlama da en önemli basamaklardır. Önceleri doğaya karşı okunan şiirler, belli bir zamandan sonra insanlara karşı okunmayla süreç devam eder. Bunun sonucunda Hurşit'in günlük yaşamında âşıklık temel kişilik özelliği olarak ortaya çıkar. Böylelikle öznel dünyasına yöneliklik artık dış ve nesnel dünyaya yönelmeye başlamıştır. Hurşit'in şiir söyleme yetisiyle birlikte diğer insanlardan farklılaşma süreci de başlamış olur. Bu süreç aslında onun bireyselleşme sürecidir. Şiir söyleyerek bireyselleşme bilinç alanının genişlemesinde önemli rol oynamaktadır.

\subsection{Ego}

Gördüğü rüyayla birlikte "âşık olma” Hurşit'in bilinç düzeyine çıkar ve böylece egosu hikâyeyi "âşık" kimliğiyle sürdürmeyi seçer. Âşı kimliği çok sayda duygunun bilincinde yer etmesine yol açmıştır. Hurşit özel yaşamında kendi güzelliğinin dışında hiçbir kızı beğenmeyen içedönük biriyken bilinçdışında bu durum rüyada kendini göstermiştir.

\subsection{Kompleks}

Kişisel bilinçdışının içindeki bir takım düşünce ve duygular kendi aralarında gruplaşarak "kompleks" adı verilen durumu meydana getirirler. Özerk bir şekilde işleyen kompleksin kendi güdüleyici özellikleri insanı kuvvetli bir denetimde tutarlar (Geçtan, 1998: 175). Rüya kompleks bir yapıdır. Hurşit'i güdülemiş ve sevdiğine kavuşabilmek için bir çabanın içine girmesini sağlamıştır.

\section{Gurbete Çıkma:}

Hurşit kırk dervişin söylediği yedi aylık süre dolunca rüyasında gördüğü Murattepe’ye doğru yola çıkar. Ceylan Yaylası denilen yere gelir. Bu bölge babasının mülkleri arasındadır. Hurşit yaylada birçok çadırın kurulduğunu görür. Hurşit'in yayla sahibi padişahın oğlu olduğunu bilmeyen yaylacılarla aralarında çekişme olur. Mahmihri gelerek tartışmanın arasına girer. Hurşit rüyasında âşık olduğu kızla karşılaşınca bayılır. Mahmihri, yaşlı hoca bir kadının tavsiyesine uyarak bir çadır kurdurup baygın Hurşit’i buraya taşıtır ve gögüslerini koklatarak ayıltır. Karşılıklı beyit okurlar. Örneğin:

Ald1 k1z:

Ey arslan yiğidim, sen nereden geldin?

Uzun ahlar çektin, kalbimi deldin.

Benim Mahlığımı sen nasıl bildin?

Var git yiğidim, benden 1rak gez.

Aldı Hurşit: 
Ben dertli Hurşit'im yaktım kavımı,

Yana yana buldum en son tavim1,

İşte yakaladım şimdi avımı,

Başın için çekme kendini benden.

Hurşit ile Mahmihri gördükleri rüyayı birbirlerine anlatarak aşk şarabını içerler.

Hikâyede "aşk şarabı" rüyada dervişlerin sunduğu dolu olarak değil de iki sevgilinin öpüşmesi olarak verilmiştir. Aşk dolusu, aşk şerbeti, aşk badesi de olarak bilinen ancak en yaygını aşk şarabı olan motif somut anlamda verilmiştir.

Ald1 k1z:

Bana da o kırklar gösterdi seni,

Bizi kavuşturdu yaratan Gani

Uğruna fedadır bu tatlı canı

Muhabbetli yârim, sen safa geldin.

Aldı Hurşit:

Aşk ateşinden yandım hastayım

Çadır içinde değil altın tastayım,

Şu ince beline bir el atayım

Benim şirin meleğim ben sana geldim (Gürgen, 1973: 19-20).

Mahmihri, Hurşit'e Büyük Han denilen kişinin kendisiyle zorla evlenmek istediğinin bu yüzden memleketlerinden kaçtıklarını anlatır. Kızın kardeşleri Hurşit'e yaylayı satın almak istediklerini söylerler. Hurşit, yaylanın babasının malı olduğunu söyleyerek onları saraya davet eder. Hurşit saraya dönerken ayrılık acısıyla Mahmihri'yle karşılıklı söyleşirler:

Aldı Hurşit:

Kara gözlü nazlı yârim,

Yâr yârdan nice ayrilır?

Oynar, kalkar, helâlleşir

Yâr, yârdan nice ayrilır?

Ald1 k1z:

Git yiğidim güle güle

Bir gün gene kavuşuruz,

Düşmeliyim şimdi dile,

Bir gün gene kavuşuruz. (Gürgen, 1973: 25)

Hurşit saraya dönerek rüyasını ve başından geçenleri babasına anlatır. Durumu öğrenen padişah yedi kardeşi huzuruna kabul eder. Yaylayı kardeşlere hediye ederek kız kardeşlerini oğluna ister. Böylece Hurşit ile Mahmihri’nin sözü kesilir. Her iş yoluna girince düğün hazırlıkları başlar. Bir ay sonra yedi kardeş kız kardeşlerini Hurşit'e vermekten vazgeçtikleri haberini padişaha gönderirler. Haberi alan Hurşit doğruca Ceylan Yaylasına gider fakat yaylada bütün çadırlar sökülmüş kimse kalmamıştır. Hurşit üzüntüsünden uzun bir şiir okur. Bir dörtlüğü şöyledir: 
Issızlık kaplamış bütün her yanı,

Başımdan savuşmuş aşkın dumanı,

Elvan elvan olmuş çayır çimeni,

Aman yayla, hani senin merâlin? (Gürgen, 1973: 30)

Hurşit, Mahmihri'yle oturduğu taşın arasına sıkışmış bir kâğıt görür. Kâğıtta şu şiirden parçalar yazılıdır:

Cad1 karı geldi, bizi doyurdu

Zalim kardeşlerim böyle buyurdu

Felek Hurşit'imden beni ayırdı

Gene uğrattılar beni yollara

Şiirli mektubu okuyan Hurşit ne pahasına olursa olsun sevgilisini aramaya karar verir. Yaylalarda yollarda saz çalıp söyleyerek dolaşır:

Dağların içinde buldum yolları,

Yollar ne diyara gitti sevgilim?

Kandır gözlerimin coşkun selleri,

Seller, ne diyara gitti sevgilim? (Gürgen, 1973: 33)

Hurşit başka yaylaları dolaşırken bir çobana rastlar. Mahmihri bu yaylada üç gün kalmış ve çobanla Hurşit'e haber bırakmıştır. Bu durumu Hurşit'le çoban karşılıklı deyişlerle anlatırlar:

Aldı Çoban:

Mevlâm kavuştursun nazlı yârine,

Sana selâm taşı attı da gitti

Düşmek çok zor imiş aşkın nârine,

Burada üç gece yattı da gitti.

Aldı Hurşit:

Çoban, sen o yâri iyi gördün mü?

Bizim sırrımıza sen de erdin mi?

Benim ahvalimi yâre sordun mu?

Aman ne diyara gitti sevgilim? (Gürgen, 1973: 34)

O gece yaylada kalan Hurşit, sabah oradan ayrılıp on gün sonunda İçmaan şehrine gelir. Yaşlı bir adamdan şehrin Büyük Han'ıyla Mahmihri'nin düğünü olduğunu öğrenir. Şehirde ihtiyar bir kadının yanında kalmak için yalvarır. Kadın Hurşit’in padişah oğlu olduğunu anlayınca kalmasına izin verir. İhtiyar kadın Hurşit'e canın sıkılmasın git biraz şehri gez diye gönderir. Şehrin meydanındaki büyük bir çadırda kızlar ve onlara hizmet eden cariyeler vardır. Hurşit kızlara beyitler okur. Örnek:

Hurşit'im, babamın bir handır aslı,

Yüreğim yaralı ciğerim paslı,

Yârimi kaybettim, tutarım yası 
Ben kara giyeyim, al sizin olsun (Gürgen, 1973: 36)

Kızların içinde o civardaki bir beyin kızı da vardır. Kız Hurşit'i görünce ona âşı olur. Hurşit kızın duygularını öğrenince: "Senin gibi bey kızı ile muhabbet benim ne haddime!" deyince Kız bu duruma üzülür. Kızla Hurşit karşılıklı saz çalıp deyiş söylerler:

Ald1 Kız: $\quad$ Beyim ne semtten gelirsin

Ağam al beni, sar beni

Aklımı başımdan alırsın

Paşam al beni, sar beni

Aldı Hurşit: Geldiğim diyar bilinmez,

Gözyaşlarım hiç silinmez,

Derdime çare bulunmaz,

Ey bac1, alamam seni.

Aldı Kız: Aşk şarabını içelim,

Birlikte kalkıp göçelim

Yüce dağlardan aşalım,

Ağam, al beni, sar beni.

Aldı Hurşit: $\quad$ Hurşit'im vardır bir Mah'ım

Yâr üstüne düştü rahım

Mah içindir bütün ahım,

Ey bac1, alamam seni.

Karşılıklı deyişlerden sonra Hurşit oradan uzaklaşınca kız tayesinin yanına giderek arkadaşı Mahmihri’nin sevgilisine bilmeden laf attığını hatasını anlayıp onun gönlünü almak istediğini söyler. Hurşit gelerek nasıl âşık olduğunu onlara anlatır. Hurşit kızların yanından ayrılarak konuğu olduğu ihtiyar kadının yanına gelir. Kadının adı Hasret’tir ve deyiş söylemesini de bilmektedir. Karşıllklı söyleşirler:

Aldı Hurşit: Gül, dertli bülbülün dertsiz yâridir,

Bir âşı̆̆ın ahı taşı eritir,

Benim nazlı yârim de Mahmihri'dir,

Aman nine o yâr için ağlarım.

Aldı Hasret: Hasret der ki; oğlum niçin ağlarsın

Ağlayıp da niçin sine dağlarsın,

Mah'ın düğünü var, sen ne söylersin

Söyle o yârinden haber vereyim.

$\mathrm{Bu}$ deyiş̧me sonucunda Hurşit, Mahmihri'nin düğünü olduğunu ihtiyar kadından öğrenir (Gürgen, 1973: 40-41). 


\subsection{Persona Arketipi}

Sahne sanatçılarının birtakım roller için taktıkları maskeye persona denir. Analitik psikolojide ise başkalarının onayını almak için kişinin insanlara karşı takındığı maske veya kimlik olarak değerlendirilir. Her insanın çevresiyle iyi ilişkiler kurabilmesi veya sevmediği kişilerle birlikteyken de onları idare edebilmek için yardımcı olur (Geçtan, 1989: 179). Hurşit'in de hikâyede karşılaştığı durumları idare edebilmesi ve insanlarla ilişki kurabilmesi için takındığı maskeleri vardır. Bunlardan birincisinde bir bey kızı Hurşit'i görünce ona âşık olur. Ancak Hurşit, kendisi padişah oğlu olduğu halde kendisinin şehzade kimliğini saklar. Kızla iyi ilişkiler kurabilmek için "Senin gibi bir bey kızı ile muhabbet, benim ne haddime ..." diyerek şehzade kimliğini gizleyerek sadece "âşı" kimliğini öne çıkaracaktır. Kızın kendisi de saz çalıp deyiș söylemesini bilmektedir. Hurşit ile karş1lıklı söyleşme süresince kı, Hurşit'e kur yapar. Ancak Hurşit kızın duygularına karşılık vermediği gibi takındığı kimliği de sürdürmeye devam eder. Diğer bir örnek de Hurşit'in Büyük Han'ı kandırabilmek için girdiği âşık kimliğidir. Bu maske yapılan plan gereği biraz da zorunluluktan takılmıştır. Hurşit, Mahmihri'nin alıkonulduğu saraya girebilmek ve Mahmihri'nin kardeşleriyle tasarladıkları planı uygulayabilmek amacıyla sıradan bir saz çalıp çığıran âşık kimliğine bürünmüştür. Hanın huzurunda âşık rolünü başarıyla yerine getirir çünkü Han'ın kendisi de aslında âşıktır.

\subsection{Gölge Arketipi}

Jung'a göre her insanın içinde ikinci bir kişilik vardır. İçimizdeki gizli kişilik yani karanlık tarafa gölge/karanlık arketipi denilir. İçmaan şehrinin kolcusu bezirgân hastalanıp ölünce kolculuk görevi onun adamlarından Kara Yüzbaşı adlı birisine verilir. Kara Yüzbaşı göreve gelir gelmez içindeki gizli kişiliği yani karanlık tarafi ortaya çıkar. Gölge, kişinin güçlü yönlerini ortaya çıkarır. Kara Yüzbaşı'nın güçlü tarafı insanları organize edebilmesi ve yönetme yeteneğidir. Kara Yüzbaşı'nın gölgesi de öne çıkarak önce diğer insanların kendisine "büyük han" demelerini isteyerek kendisini şehrin kolcusundan ziyade hanı olarak kabul ettirmek ve bu konumu korumak için de asker sayısını artırmak yoluna gider. Zamanla gölge, Yüzbaşı'nın egosu üzerine egemenlik kurmaya ve onun yönetimi ele almaya başlar. Sadece ölen kolcunun görevini değil kızını da alarak kendi otoritesini kabul ettirme ve sınıf atlama içgüdüsünü ortaya çıkarır.

\section{Kavușma:}

İhtiyar Kadın Hurşit'e üzülmemesini, üç oğlunun da sarayda olduğunu onun bu derdine bir çare bulabileceklerini söyler. Bir plan yapılır. Buna göre üç kardeş, Hurşit'i alarak saraya Büyük Han'ın huzuruna getirerek akrabaları olarak tanıtırlar. İyi saz çalıp söylediğinden bahsederler. Büyük Han ona Hurşit adlı bir âşığı tanıyıp tanımadığını sorar. Hurşit yapılan plan gereği davranır Hurşit'i tanıdığını ve ondan deyişler çalıp söyler. Örnek:

Benim bir derdim var Han'a söylenmez,

Çektiğim gizli dert halka yayılmaz

Ellere yâr olur, bana yâr olmaz,

Benim gönlüm dilber cana maildir.

Büyük Han Hurşit'ten memnun kalır. Bu arada üç kardeş de Mahmihri'yi getirip Hurşit'i dinletmişlerdir. İki sevgili kavuşurlar. Büyük Han içkiden sarhoş olup kendinden geçince kardeşler has bahçede bulunan sevgililere at getirip kaçmalarını sağladılar. Büyük Han sabah ayılıp da âşıkların kaçtığını haber alınca yanına askerlerini alarak peşlerine düşer. Yorgunluktan uyuyakalan âşıklar uyandıklarında atlıların dört koldan kendilerini sardıklarını görürler. Âşıkların Tanrı'ya sığınmaktan başka çareleri kalmamıştır.

Ald Kız: Ben bir Mahmihri’yim, sana inandım, 
Hasret ateşiyle sarardım, soldum

Gelen düşmanları gözümle gördüm,

Düşman söz dinlemez, buna ne dersin?

Aldı Hurşit: Tanrım iyi bilir benim halimi,

Korkarım alırlar nazlı yârimi,

Yad eller koklarsa nazlı gülümü,

Hasret kıyamete kalır, ne dersin?

Âşıklar böyle deyip başka çare bulamayıp atlılara doğru yürümeye başlarlar. En önde Büyük Han kılıcını çekmiş gelirken atının ayağı kayar. Han hendeğe yuvarlanıp oracıkta can verir. Askerlerin kargaşasından yararlanan âşıklar ortadan kaybolurlar. Âşıklar kaça kaça Kırk haramilerin yaşadığı bölgeye gelirler. Haramilerin reisi kızı yakalamalarını oğlanında kellesinin uçurulmasını emreder. Kız yakalanıp mağaraya götürülür. Oğlan da Arap cellâda teslim edilir. Arap, Hurşit'in padişah oğlu olduğunu öğrenince fikrini değiştirir. Arap: "Bir kuş vurup keser kanını gömleğine bular seni kestim diye götürürüm sevgilini de kurtarıp sizi babanın sarayına götürür büyük bir rütbe alırım.” diye plan yapar. Sonuçta dediğini yaparak Hurşit’i serbest bırakır. Hurşit ve Arap Mahmihri'yi mağaradan kurtararak ülkelerine dönerek evlenirler. Arap ise ödüllendirilir (Gürgen, 1973: 48-55).

\subsection{Ben Arketipi}

Kolektif bilinçdışının merkezdeki arketipi "ben" arketipidir. Ben arketipi, diğer bütün arketipleri ve onların bilinç düzeyinde ortaya çıkmalarını organize ederek kişiliğin bütünleşmesini meydana getirir. Ben'in amacı kişinin kendini gerçekleştirmesidir. Hikâyenin başından sonuna kadar Hurşit kendini gerçekleştirme çabası içindedir. Bunu sağlayabilmek için uzun, güç ve zorlu yolları aşması gerekmiştir. Hurşit'in ben olmayı gerçekleştirebilmesi için rüyasında gördüğu ihtiyar adamın etkisiyle âşı olmuş ve rüya boyunca kadınsı ve sıradan bir kişiden şiir söyleyen ve aşkı için her türlü mücadeleyi göze alan kişiliğe doğru bir dönüşüm geçirmiştir. İhtiyar adamın belirlediği yedi aylık beklemede erginleşme süresinde egosuyla işbirliği yapmış ve ego ben'in çağrılarına uyarak Hurşit'in kendini tanımasına imkân vermiştir. Ben arketipinin gelişmesiyle Hurşit kendini daha iyi tanımış Mahmihri’ye kavuşmak ve istediği yaşama ulaşmak uğruna büyük bir çaba göstermiştir.

\section{Sonuç}

Arketipin görülebilmesi için onu harekete geçirecek bir olgunun bulunması gerekir. Yapılan çalışmanın sonucunda Hurşit ile Mahmihri hikâyesinde bulunan tiplerin ve epizotlarının her birinin içinde bir ya da birkaç arketipe tekabül ettiği görülmektedir. Hikâyenin içinde arketipin algılanabilmesi için onun tetiklenmesi gerekmektedir. İnsan beyninin zihinsel işlevi, bireysel olduğu kadar aynı zamanda kolektif ve evrenseldir. Farklı insan gruplarının bilinçdışı süreçlerinin benzerlik sergilemesi diğer hikâyeler arasındaki sıra dışı ama doğruluğu kanıtlanmış benzerlik göstermesini açıklamaktadır. Türklerin en eski inanışlarında boz atlı yol iyesi, boz atlı Hızır'a dönüşmüş olarak farklı formlarla halk hikâyelerinde kendini gösterir. Hikâyede hem erkek çocuğu olmayan padişaha elma yedirerek çocuk sahibi olmasını sağlama hem de kahramanın rüyasında ortaya çıkması vardır. Hikâyede rüyanın anlamı, öznenin yani Hurşit'in psikolojik durumuyla uyum içindedir. Hikâyede Hurşit ve Mahmihri'nin gördüğü rüyalar kahramanın doğası gereği birçok benzerliği ortaya çıkarır; sevgilinin resmiyle ilk defa karşılaşma, âşılık yetisi kazanma sıradan bir rüyada kesinlikle rastlanamayacak şeylerdir. Hikâyede hikâye kahramanın ailesinin erkek çocuğu olmaması ve kahramanın gördüğü rüyaların aşağı yukarı diğer birçok hikâyede birbirine benzer bir şekilde görülmesi kolektif bilinçdışını bir göstergesi olan İhtiyar adam arketipidir. İhtiyar adam (Hızır, kırklardan biri) elma, sevgilinin resmi gibi imgeleri kullanarak bir 
türlü herhangi bir kızı sevmeyen/sevemeyen Hurşit'e imgeler vasıtasıyla ne kadar bir sürede dönüşebileceğini ve nasıl bir yol takip edebileceğini göstermiştir.

Jung'un belirttiği gibi her arketipin dişi ve eril ruhta ayrı görünüşleri ve görevleri olduğunu işaret etmiştir. Örneğin "tamamlayıcı ruh imgesi” erkekte "anima" olarak görülür. Hurşit, padişah babası tarafından şımartılarak büyütüldüğü gibi doğuştan yakışıklıdan ziyade "çok güzel" olarak kabul edildiği için hiçbir kızı kendine denk görmemektedir. Bu sebeple davranışlarının daha çok kadınsı olması, içindeki anima arketipinin bir yansıması olarak ortaya çıkmıştır. Hurşit'in içindeki kadınsılığın geri plana itilmesi ve kişiliğinin oturması için rüya görmesiyle bir süreç başlamıştır. Hurşit, rüyasında ihtiyar adamın etkisiyle bir dönüşüm geçirmiştir. Rüyada gördüğü sevgili imgesinin gerçek hayatta karşıllı̆̆ canlı bir varlık olarak Mahmihri'dir. Yedi aylık erginleşme sürecinden sonra kutsal addedilen yerde bir tepede onunla karşılaşacaktır. Arketipler ruha ilişkin gizil gücü temsil ederler. Ölen amirinin yerine geçen yüzbaşı belirsiz olarak içinde yaşattığı karanlık tarafı ortaya çıkarır. Güçlü bir lidere dönüsşen yüzbaşıda gölge arketipi tezahür eder. Hikâyede Hurşit'in erginleşme ve sonunda kişiliğinin oturması için birbirinden farklı arketiplerin tezahürü söz konusudur Anima arketipinin değişimi bireysellik ve ben arketipinin oluşumuna sebep olmuştur. Birbirlerini tamamlayıcı arketipler Hurşit'in ruhsal bütünlügünün sağlanması anlamını taşımaktadır. Hikâyede hiçbir arketip tesadüfen yer almaz. Olayların ve ona bağlı arketiplerin gelişmesi birbirini takip etmektedir. Kara Yüzbaşı'nın Büyük Han olmasıyla içindeki karanlık tarafın yani gölge arketipin çıkması ve Hurşit'in Han'ı kandırabilmek için farklı bir kişiliğe bürünmesi persona arketipi gibi sebep sonuç ilişkisi içindedir. Olay ve kişilerin birçok yönü olduğu ve genelde birbirini tamamlamaya doğru gelişme gösterdiği söylenebilir.

\section{Kaynakça}

Abraham, K. (2017). Rüyalar ve Mitler, (Çev: Emine Nur Gökçe), Pinhan Yayıncılık.

Alay, O. (2012). Evvel mi Gelsin Sonra mı? Masalı ile Gündeşoğlu Halk Hikâyesinin Arketipsel Tahlili, Milli Folklor Dergisi, 24(96), 58-66.

Campbell, J. (2010). Kahramanın Sonsuz Yolculuğu, (Çev.: Sabri Gürses), Kabalcı Yayınevi.

Duymaz, A.- Sakaoğlu, S. (1996). Hurşit ile Mahmihri Hikâyesi, Kültür Bakanlığı Yayınları.

Geçtan, E. (1998). Psikanaliz ve Sonrası, Remzi Kitabevi.

Gülerer, S. (2020). Türk Halk Hikâyelerinde İhtiyar Adam Arketipi, Sosyal Bilimler Dergisi (The Journal of Social Sciences), 7(44), 166-185.

Gürgen, F. (1973). Hurşit ile Mahmihri, Sağlam Kitabevi.

Gürses, İ. (2007). Jung'cu Arketip Teorisi Bağlamında Tasavvufî Öykülerin Değerlendirilmesi: Simurg Örneği, T.C. Uludă̆ Üniversitesi, İlahiyat Fakültesi Dergisi, 16(1), 77-96.

Irmak Y.- Ava, U. (2017). Âş1k Garip Hikâyesinde Arkatipsel Sembolizm, Dede Korkut Uluslararası Türk Dili ve Edebiyatı Araştırmaları Dergisi, 6(13), 16-28.

Jung, C. G. (2011). Dört Arketip, (Çev.: İhsan Kırımlı), Sayfa Yayınları.

Jung, C. G. (2016). Analitik Psikoloji Üzerine İki Deneme, (Çev.: İsmail Hakkı Y1lmaz), Pinhan Yayıncilik.

Jung, C. G. (2017). Rüyalar, (Çev.: Aylin Kayapalı), Pinhan Yayıncılık.

Jung, C. G. (2018). Jung ve Arketip Kavramı, (Çev.: Sercan Karahanlı), Mavi’nin Not Defteri Yayınevi.

Jung, C. G. (2019). Dönüşüm Sembolleri, (Çev.: Firuzan Gürbüz Gerhold), Alfa. 
Kitabı Mukaddes Eski ve Yeni Ahit (Tevrat ve İncil) (1993), Kitabı Mukaddes Şirketi.

Kur'an-1 Kerim Meâli (2010) (Haz.: Altuntaş, Halil/Şahin Muzaffer), Diyanet İşleri Başkanlığ1 Dini Yayınlar Dairesi Başkanlığı.

Sigmund, F. (2000). Rüyaların Yorumu I, (Çev.: Selçuk Budak), Öteki Yayınevi.

Sigmund, F. (2000). Psikanaliz Üzerine, (Çev.: Kâmuran Şipal), Cem Yayınevi.

Rank, O. (2016). Kahramanin Doğuş Miti, Mitolojinin Psikolojik Yorumu, (Çev.: Gökçe Yavaş), Pinhan Yayıncilık. 